\title{
The Impact of Clove Import Policy on Clove Market and Cigarette Production in Indonesia
}

\author{
Antik Suprihanti \\ Department of Agribusiness \\ Pembangunan Nasional "Veteran" University \\ Condong Catur, Yogyakarta, Indonesia \\ Department of Resource and Environmental Economics \\ Bogor Agricultural University \\ Darmaga, Bogor, Indonesia \\ antik.s@upnyk.ac.id \\ Harianto \\ Department of Resource and Environmental Economics \\ Bogor Agricultural University \\ Darmaga, Bogor, Indonesia \\ harianto.ipb@gmail.com
}

\begin{abstract}
Indonesian government has applied clove import policy (which import only through licensed importer). The policy had caused consequences to the clove market and cigarette production. The aim of this research was to analyze the impact of the policy on clove market and cigarette production in Indonesia. This research used data series of 1990-2016 with the model of simultaneous equation system that have been estimated using 2SLS (Two-Staged Least Squares) method. The results showed that impact of clove import policy dropped the supply of clove, meanwhile demand of clove rose. Domestic clove price decreased both on industry by 3,02 percent and on farmer level by 3,96 percent and it cause the production of cigarettes increased by 0,31 percent. In the long run, the area of clove will decrease by 0,1 percent and decreased clove production by 0,03 percent. Impact of this policy more beneficial for cigarettes industries than for clove farmers. The decrease of clove price in the long period can impact on the sustainability of Indonesian clove production and can threaten the existence of Indonesian clove in the next future. Therefore, cooperation between farmers and cigarette industries and development of clove products is needed.
\end{abstract}

Keywords-- clove market, cigarette, import policy

\section{INTRODUCTION}

One of the agroindustry that plays an important role in Indonesian economy is cigarette industry. Data from [1] showed the growth of tobacco products production has increased since the last 5 years with production around 345348 billion cigarettes in the last 3 years. Cigarette agroindustry has been able to provide jobs, support the regional economy, and support state revenues in the form of cigarette

\author{
Bonar M. Sinaga \\ Department of Resource and Environmental Economics \\ Bogor Agricultural University \\ Darmaga, Bogor, Indonesia
}

Reni Kustiari

Centre Studies Economic of Agriculture Policy

Jl. Tentara Pelajar no. 3

Bogor, Indonesia

kustiarireni@yahoo.com

excise tax. [2] showed that excise revenue continued to increase, amounted to Rp.106.690.8 billion in 2013 and increased to Rp. 138,527.07 billion in 2016.

Cigarettes produced in Indonesia mostly (90.3 percent) are clove cigarettes (kretek) [3]. Clove cigarettes include Hand-Rolled Clove Cigarettes (Sigaret Kretek Tangan, SKT) and Machine-Rolled Clove Cigarettes (Sigaret Kretek Mesin, SKM) and Klobot Cigarettes (SKB). Indonesian clove cigarettes has the unique aspects that in addition to tobacco, they contain dried clove buds and are flavored with a proprietary "sauce".

The increase of clove cigarettes production, has made high demand of clove as raw material of Indonesian cigarettes. Clove cigarette industries almost absorbed 80-90 percent of Indonesian clove production [4][5] which almost 98 percent of smallholder planted its clove [6]. Although clove cigarette (kretek) contains clove buds got trade discrimination from United States [7] and be charged more dangerous for health than commercial cigarette brands available in the United States [8], consumers from other countries especially Europe tend to favour the clove cigarette (kretek) from Indonesia. Therefore, clove cigarettes industries also produced cigarette for export market besides domestic market.

The high trend of clove cigarette production in Indonesia (Figure 1) are supported by Indonesian roadmap of tobacco industry 2007-2020 which call for increased cigarette production almost 12 percent over the next 15 years [9]. This roadmap allowed transnational companies, such as Philip Moris from the U.S. (United States) developed their business in Indonesia since 2005. According to [10], transnational tobacco companies has undergone significant transformation. 


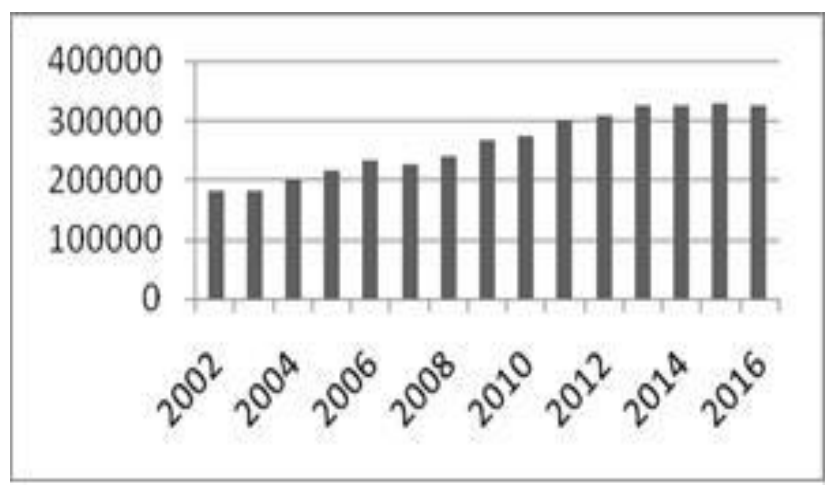

Figure 1. Production of clove cigarette 2002-2016 (million bar)

Although Indonesian goverment has signed the world trade organization agreement in world free trade, Indonesian government had applied policy to restrict imported clove (non tariff barrier). The aims of this policy is control clove importing through the Ministry of Industrial and Trade decree no: 528/MPP/2002. This decree stated that clove importing can be done only by lisensed importer from the government. This policy issued to anticipated the masive import of clove that could made not only clove price drop in farmers level, but also to accomodate stakeholders (cigarette industries) on clove need.

In fact, during the policy progress, the price of clove exactly keep stable in the lower price level but since 2011 the clove price started to rise sharply. Therefore, since September 2015, the government withdrawed the decree through Indonesian Trade Ministry regulation no: 75/MDAG/PER/9/2015 which made the clove trade opened widely. The dynamics of this policy impacted not only to the cigarette industry, but also to the clove market. Therefore, the impact of clove policy is needed to be analyzed further, especialy the impact on clove market and also on clove cigarette production as shown in Figure 2

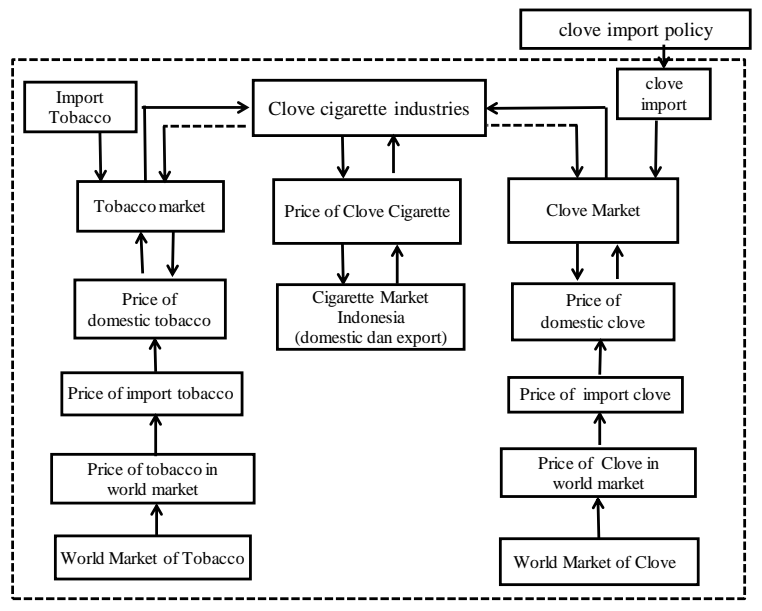

Figure 2. Operational framework of research

This research aims to analyze impact of clove import restiction on clove market and cigarette production in Indonesia. Previous research analyzed the drop of clove price and the policy option [11], other research looked at the impact of cigarette excise tax policy on Indonesian clove commodities, impact of the government trade policy on clove market [12][13]. [14] analyzed the relationship between clove industries and cigarette industries. Impact of government policy on supply, demand and employment has been done [15]. [16] focused on the dynamics of cigarette agribusiness on tobacco and clove markets and [17] analyzed the clove demand in Indonesia.

\section{METHODS}

This study used annual secondary data (time series) for 27 years from 1990-2016. The data sources were from the Ministry of Finance (Directorate General of Customs and Excise), Indonesian Cigarette Manufacturers Association (GAPPRI), United Nations Commodity Trade Statistics Database (UNCOMTRADE), Central Bureau of Statistics, Food and Agricultural Organization, Directorate General of Plantation Ministry of Agriculture, Index Mundi, Food and Agriculture Organization Statistics (FAOSTAT), World Bank and other related literatures.

The econometric method was use which consisted of model identification, estimation, and model validation. The model in this research was built in the form of simultaneous equation system consisting of three blocks of equation namely, Indonesian Tobacco Market Block, Indonesia Clove Market Block and Indonesia Clove Cigarette Market Block. In the clove cigarette market block, it was disaggregated into 3 groups, namely Machine Clove Cigarettes (SKM), Hand-Rolled Clove Cigarettes (SKT), and Klobot Clove Cigarettes (SKB). The model consisted of 63 equations which were 38 structural equations and 25 identity equations.

The result of model identification was overidentified. So, the models can be estimated using Two Stage Least Square (2SLS) method [18]. Model validation was done in order to see if the model is sufficiently valid to be used for policy simulation. The criteria used to validate the estimated value of econometric models used Root Means Squares Percent Error (RMSPE) and U-Theil. If the RMPSE is smaller, the model used will be better. Statistic value of U-Theil between 0 and 1 [19].

Impact simulation was done to see if the response that occurs on endogenous variables ware due to changes in exogenous variables (e.g policy instruments). This type of simulation is a dynamic simulation using Newton's simulation method.

\section{RESULTS AND DISCUSSION}

Indonesia is one of main producer and consumer of world clove. The dynamic of Indonesian consumption will influence the world clove market. In world market the clove is traded slightly where quantity export and quantity import almost balance. If there are any changes on world clove supply and demand, it will impact on the level of clove world price. For example the drop of clove supply from Madagascar that is main clove producerin the world can 
cause supply in the world market decrease and will increase clove world price.

In Indonesia, the availability of domestic clove is very important as raw material of clove cigarette industries. According to [4], domestic clove market very fluctuated. It was because the product cycle of clove plant and the trend of clove demand that tend to decrease cause the change of consumers preferences on clove cigarettes to mild cigarettes.

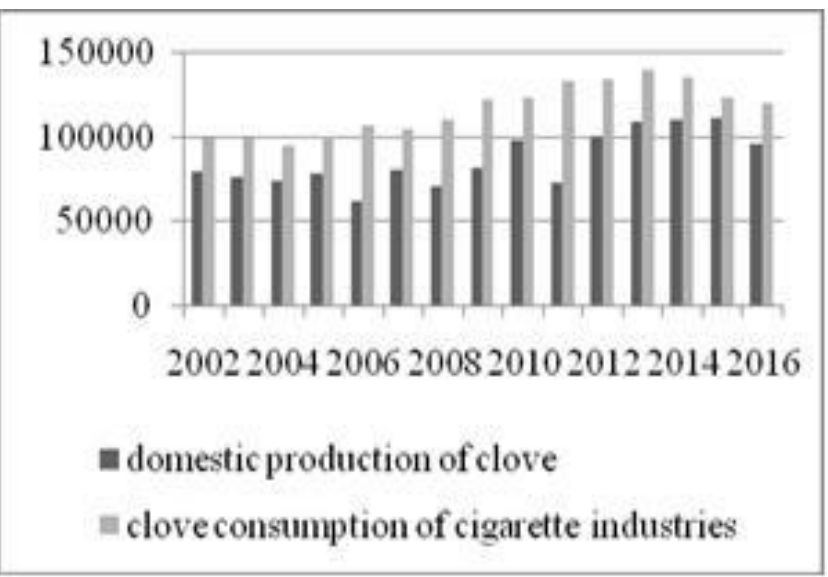

Figure 3. Production and consumption of clove 2002-2016 (ton)

Figure 3 indicated that consumption of clove was higher than domestic production. The high demand of clove comes from cigarette industries consumption mainly large scale industries such as Sampoerna/ PMI, Gudang Garam and Djarum. These cigarette companies majority used domesticclove as their raw material for their cigarette production. So, if the clove domestic production drop, it would make the clove price rise significantly.

In fact, since the policy applied in 2002, the price of clove dropped sharply and then it stable on the lower price for few years (Figure 4) [20]. According to [11], this policy only gave cigarette industry had an exclusive licence (monopoly) in clove import. The consequences, when cigarettes industries already had many stocks and then they stop clove import, the clove in world market rised and the price would drop. The impact was the declining price of domestic farmer's in the lowest level.

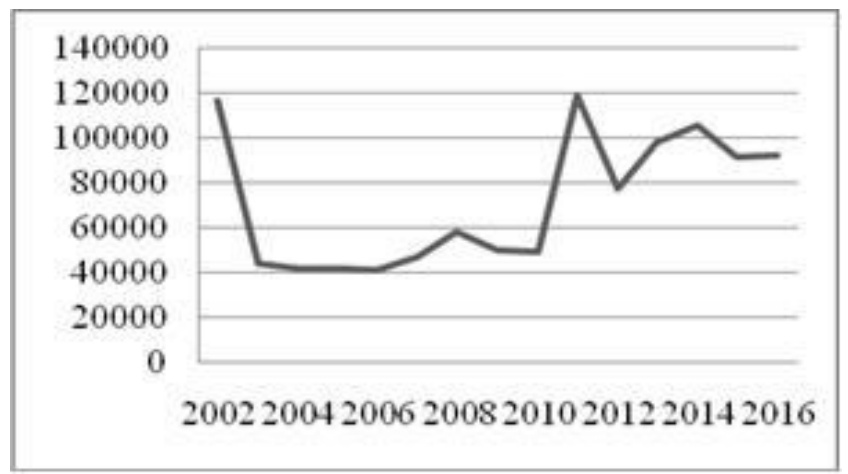

Figure 4. Trend of Indonesian domestic clove price in 2000-2016 (Rp/kilos)
This evidence showed that in case of Indonesian clove which Indonesia is not only as main consumer but also producer in the world. This policy caused domestic clove price dropped because Indonesia also supply clove in the world market. The restriction on imported clove trough licenced importer which also consumer made excess supply of clove in world market. Theoretically, the restriction import trough licensed importer should be rise the domestic price but with assumption that there are no production in importer country [21].

The price of clove that down sharply since 2003 to 2010 (almost 8 years) apparently had made farmer did not excited to manage their clove plant intensively and it made clove production decreased. The significant increased of clove price in 2011 to 2016 proved that decrease in domestic supply, caused domestic production dropped. The impact was clove import in 2011 was the highest import value all this time [16].The rise of clove demand in 2011 was suspected because of the clove stock of cigarettes industries start to diminish while domestic clove production has drop. The decrease of clove production in main production area such as in Maluku and Sulawesi would decrease the clove domestic production significantly.

The pattern of price movement (Figure 4) brought serious problem for clove plantation in Indonesia. In the long run, the lowest price will not give an incentive for the farmer then the clove production will decrease in the future. Cigarette industry also harmed because the cost of production increased by the high price of clove import.

\section{A. Estimation and validation model}

The result from simultaneous estimation on the three blocks showed that the direction and the parameter of estimation from the variables used were in line with the expectation. The determination coefficient $\left(\mathrm{R}^{2}\right)$ majority had a value between 53 to 99 percent. This finding showed that most explanatory variables in each equation were able to explain 53 to 99 percent variation of each endogenous variable.

From the validity assessment obtained RMSPE value of 81 percent of the variable which has a value below 30 percent and only 10 percent have percentages above 100 percent. The results showed that during the observation period of 2007 to 2016, the endogenous variables value of the predicted result were almost all close to the actual value. Based on the validation indicator of U-Theil value, 90 percent equations have U-Theil value below 0.3 , while 7 equations (10 percent) have U-Theil value above 0.3 but still less than 1. Based on estimation result then the model is considered good enough to be used for simulation. Simulation of a model might be performed model testing and evaluation, historical policy analysis and forcasting [22]. Policy impact simulation (import policy) on some endogenous variables further becomes the objective of the research. 


\section{B. Policy Simulation Impact Results}

This research simulated the model to historical policy analysis. Result of the policy simulation (clove import restriction) on clove market and clove cigarette production in detail can be seen in Table 1 .

Simulation result (Table 1) showed that the clove import restriction policy made the price of clove declined. This result is in line with [11] finding which was the price of clove in domestic market dropped. The simulation showed that this policy impact on the price of clove in domestic level (both in industry level and farmer level ). In the long run, the area of clove decreased and impact on the decrease of clove production .

Table 1.The impact of import clove policy on clove market and cigarettes production

Name of

\begin{tabular}{|c|c|c|c|c|}
\hline No & $\begin{array}{l}\text { Name of } \\
\text { Variable }\end{array}$ & Unit & $\begin{array}{l}\text { Base } \\
\text { Value }\end{array}$ & $\begin{array}{c}\text { Change } \\
(\%)\end{array}$ \\
\hline 1 & ACI & ha & 453096.8 & -0.10 \\
\hline 2 & QPCI & ton & 91393.52 & -0.03 \\
\hline 3 & CCSKI & ton & 124115.6 & 0.25 \\
\hline 4 & $\mathrm{CCI}$ & ton & 125962.6 & 0.25 \\
\hline 5 & QXCI & ton & 8564.949 & 1.69 \\
\hline 6 & QXCW & ton & 52770.93 & 0.28 \\
\hline 7 & QMCI & ton & 3998.087 & -5.10 \\
\hline 8 & QMCW & ton & 46139.43 & -0.44 \\
\hline 9 & QSTC & ton & 422283.9 & 0.22 \\
\hline 10 & DCI & ton & 556811.5 & 0.25 \\
\hline 11 & SCI & ton & 490479.9 & -0.05 \\
\hline 12 & PFCI & $\mathrm{Rp} / \mathrm{kg}$ & 47454.95 & -3.96 \\
\hline 13 & PCI & $\mathrm{Rp} / \mathrm{kg}$ & 73926.88 & -3.02 \\
\hline 14 & PXCI & US\$/kg & 2.82839 & -0.04 \\
\hline 15 & PMCI & US\$/kg & 6.794163 & -0.07 \\
\hline 16 & PCW & $\mathrm{US} \$ / \mathrm{kg}$ & 6.407202 & -0.06 \\
\hline 17 & QSKT & million bar & 88549.21 & 0.09 \\
\hline 18 & QSKM & million bar & 197942.7 & 0.41 \\
\hline 19 & QSKB & million bar & 607.9132 & 0.18 \\
\hline 20 & QPSKI & million bar & 287099.8 & 0.31 \\
\hline 21 & QXSKM & million bar & 43588.61 & 0.27 \\
\hline 22 & SSKI & million bar & 243511.2 & 0.32 \\
\hline
\end{tabular}

The applied of restriction on clove import policy start with the decrease of Indonesian clove import quantity (QMCI) by 5.1 percent. This impact on the quantity of world clove import (QMCW) also decreased. Because Indonesia is one of main clove consumers in the world, the decrease of import will influence the excess supply of clove in world market. In world market, excess supply will make the price of clove in world market (PCW) drop. The world market price would be transmited into import clove price (PMCI) and Indonesia export price (PXCI). Thus, it effect to the clove price in industry level (PCI) that dropped by 3.02 percent and the decreased on farmer level (PFCI) by 3.96 percent. In the long run, the decreasing of clove price will effect on the decreased of clove area (ACI) by 0.1 percent and impact on the decrease of clove production (QPCI) by 0.03 percent.

Indonesia is one of world producer and consumer clove in the world. The decline of clove price in domestic market will increase Indonesian clove export (QXCI) by 1.69 percent. Meanwhile, the domestic clove import (QMCI) by cigarette industries will decrease cause they have already stock clove for the next few years. In domestic market supply of clove (SCI) dropped by 0.05 percent because imported clove decreased besides domestic clove production dropped by climate change. On the other hand, demand of clove (DCI) rose by 0.25 percent cause the export of Indonesian clove rised.

For clove stakeholders mainly the high scale industries, the decrease of clove price will be profitable because minimize their cost of production. This situasion will give opportunities to the industry to buy clove cheaply more for the stocks until the next 4 years. Impact of this policy, the companies also could rise their cigarette production significantly to enhance their profit along with their intense promotion.

Result of this simulation showed that the decrease of clove price made the high increase of clove consumption of cigarettes industries (CCSKI) by 0.25 percent and impact on the increase of clove cigarettes production (QPSKI) by 0.3 percent. The cigarettes production on SKT (QSKT), SKM (QSKM) and SKB (QSKB) increased by 0.09 percent, 0.41 percent and 0.18 percent respectively. Production of SKM is the highest beetween the three types of clove cigarettes. The quantity of clove cigarettes export (is dominated by SKM) also tend to increase about 0.27 percent. This result was the same with [15] that found that the rised of clove price has significant implact on the clove cigarette export.

The applied of this policy had made the cigarettes industries especial large companies got big opportunities to increase their production with their import lisenced. This policy had supported cigarettes industries to expand their business in Indonesia besides other goverment policy such as industry tobacco product roadmap. The high trend of clove cigarettes production for almost a decay was supported by Indonesian tobacco industry roadmap 20072020 that give the opportunies cigarettes industry to increase their production until 2020 until 12 percent [9].

This policy also impact on tobacco consumption that is complement raw material of clove cigarette. Simulation showed that the increase of clove for cigarettes production outomaticly increased the demand of tobacco. It indicated from the increase of tobacco import since 2010. According to [23], local tobacco do not have technical spesification standards yet, so cigarette industry has to bear the cost of regrading in order to local tobacco can be used by them.

The restriction of clove import policy evidently gave big impact on the decrease of clove price not only on industry level but also on farmer level. Although this policy more beneficial for the industries of clove cigarettes, but this policy will make the domestic clove price dropped and 
decrease the farmer income. This policy ultimately only beneficial for the cigarette industries especially large scale industries that has strong capital back up.

Indonesia is one of main clove consumer in the world, so the change of Indonesian consumption will influence the clove market. If Indonesian importer which is representative of clove cigarettes industries stop their import, it will make an over supply of clove in world market, so the price dropped. The change of price in world market affected to clove import price and to the price of clove in domestic market.

This decrease of clove price in the long run caused the farmer did not have proper incentives to maintain their clove plant, so the production would decreased. If this policy is applied for the long period, it will impact on the drop of Indonesian clove production and could threaten the existence of clove farming in Indonesia.

Thus, this fact shows that Indonesian clove production still depend on demand of cigarette industries. There are no incentive price for clove production due to the monopoly power of cigarettes industry. It has made Indonesian clove production fluctuated with slowly growth [16]. The significant growth of cigarettes production for almost 15 years which is started since 2007 only beneficial for the cigarettes industries and do not give much benefit for the farmer as supplier of cigarettes raw material. The lack of raw material was fulfilled by importing clove and also tobacco without developing effort. [3] and [9] predicted Indonesia will become a country for transnational companies that expansion their business by using weaknesses of Indonesia cigarettes regulation. Meanwhile [24] stated that in the future of the tobacco-produced disease epidemic rests in low- and middle-income countries, where cigarette sales are growing as the result of rising incomes, trade liberalization, liberalization of the treatment of women, and the introduction of Western-style advertising.

In the future, Indonesia only became net importer and the existence of Indonesian clove in the world market will be lost. According to [25] the intervention policy may lead to a wasteful allocation of resources cause the government often subsidise the private sector's input even when the private sector itself is willing to spend at the prevailing market rate and risk. This type of protection has led to cronyism and bad investments decisions in the past.

The impact of policy actually should be beneficial for all the stakeholder. The cigarette industry as the consumer and the clove farmer as producer has interdependency on clove. Therefore, cooperation between farmer and cigarette industries need to be consideration [14]. The applied of clove policy must be accomodation the clove farmer price trough the minimum price.

To keep the existence of clove as one of typical Indonesia tropical plant in the next future, the government has to support development of Indonesian clove. The research for diversification clove products besides clove cigarettes such as for essensial oil, preservatives and the others must be more intensive as case in Tanzania. The Government of the United Republic of Tanzania has acted to regenerate production through policy and law reforms. The initiatives, which include supporting the purchase of cloves from farmers, exports and production of essential oils, have resulted in increased production and prices [26].

\section{CONCLUSION}

The applied of clove import policy impact on the supply of clove dropped and demand of clove rose. Domestic clove price decreased both on industry by 3.02 percent and on farmer level by 3.96 percent and it cause the production of cigarettes increased by 0.31 percent. In the long run, the area of clove will decrease by 0.1 percent and impact to the decrease on clove production by 0.03 percent. Impact of this policy more beneficial for cigarettes industries than for clove farmers. The decrease of clove price in the long period can impact on the sustainability of Indonesian clove production and can threaten the existence of Indonesian clove in the next future.

The impact of policy should be beneficial for all the stakeholder. Therefore, cooperation between farmers and cigarette industries is needed to keep existency of clove cigarettes. The clove policy must take into account the clove farmer concerning clove price. The government has to support development of Indonesian clove products. The research and development for diversification of clove products such as clove for essensial oil, preservatives and others must be more intensive. So the dependency of farmer clove on the clove cigarettes industries can be minimized.

\section{ACKNOWLEDGMENT}

This study is a part of doctoral dissertation and funded by The Ministry of Research, Technology and Higher Education of the Republic of Indonesia (Grant No 084/SP2H/LT/DRPM/2018)

\section{REFERENCES}

[1] Ministry of Finance, Kebijakan Cukai Hasil Tembakau: Round Table Discussion Rokok, Perspektif Kesehatan Masyarakat Vs Perspektif Ekonomi, University of Indonesia, 2016. https://www.fkmui.ac.id

[2] Directorate General of Customs and Excise, Laporan Kinerja Direktorat Jenderal Bea dan Cukai Kementerian Keuangan, 2017.

[3] M. Rachmat, "Pengembangan Ekonomi Tembakau Nasional: Kebijakan Negara Maju dan Pembelajaran Bagi Indonesia.” Jurnal Analisis Kebijakan Pertanian. Vol. 8, pp. 67-83, 2010.

[4] A.Wahyudi,"Kebutuhan Cengkeh untuk Industri Rokok Kretek", Infotek Perkebunan, Vol 4, December 2012. Accessed 15 March 2016. http:// perkebunan. litbang.pertanian.go.id.

[5] Ministry of Agriculture, Outlook Komoditi Cengkeh. Jakarta: Pusat Data dan Sistem Informasi Pertanian, Sekretariat Jenderal Kementerian Pertanian, 2014.

[6] Directorate General of Estate, Tree Crop Estate Statistics of Indonesia, Clove Commodity 2013-2015, Secretariat of Directorate General of Estate, Ministry of Agriculture, Jakarta, 2014.

[7] Bridges, Indonesia Announces Deal with US on Clove Cigarettes Trade Dispute, Bridges, vol. 18, 2014 https://www.ictsd.org/bridges-news/bridges 
[8] J. R. V. Nadel and G.N. Coolly, Disparities in Global Tobacco Harm Reduction. Letter on American Journal of Public Health, vol. 95, 2005.

[9] R.D. Hurt, O. E. Jon, A. Anhari, and T. C. Ivana, "Roadmap to a tobacco epidemic, transnational tobacco companies invade Indonesia", Research paper, Tobacco Control May 2012, vol. 21, pp. 306-312, 2012.

[10] K. Lee and J. Eckhardt, "The globalisation strategies of five Asian tobacco companies, An analytical framework". Global public health, vol. 12, pp. 269-280, 2017.

[11] P. Simatupang, "Opsi Kebijakan Memulihkan Anjlok Harga Cengkeh". Jurnal Analisis Kebijakan Pertanian. Vol 1, pp 297-305, 2003.

[12] A. Wachjutomo, Analisis dampak Kebijakan Pemerintah terhadap Penawaran dan Permintaan Cengkeh di Indonesia, Tesis (Unpublished), Bogor Agricultural University, 1996

[13] T. H. Situmeang, Analisis Produksi, Konsumsi dan Harga Cengkeh Indonesia, Bogor Agricultural University, 2008.

[14] G. A. J., .Rumagit, Kajian Ekonomi Keterkaitan antara Perkembangan Industri Cengkeh dan Industri Rokok Kretek Nasional, Dissertation, Bogor Agricultural University, 2007.

[15] S. Harini, "Dampak Kebijakan Pemeritah terhadap Keragaan Industri Rokok Kretek Indonesia”, Thesis, Bogor Agricultural University, 2001.

[16] A. Suprihanti, "The Agribusiness Dynamics of Indonesian Cigarettes and Its Implication on Tobacco and Clove Market". Proceeding International Conference Strengthening Indonesia Agribusiness. Bogor, pp 33-41, 2016.

[17] V. A. Rumate, Permintaan Cengkeh di Indonesia, Tesis, Gajah Mada University, Yogyakarta, 1992.

[18] M. Intriligator, R. Bodkin, and C. Hsiao, Econometric Models, Techniques, and Applications, Second Edition, Prentice-Hall, Inc, 1996.

[19] RK Sitepu, BM Sinaga, Aplikasi Model Ekonometrika. IPB Press, Kota Bogor-Indonesia, 2018.

[20] Directorate General of Estate, Tree Crop Estate Statistics of Indonesia, Clove Commodity 2015-2017, Secretariat of Directorate General of Estate, Ministry of Agriculture. Jakarta, 2016.

[21] Nopirin, Ekonomi Internasional, BPFE: Yogyakarta, 1996.

[22] R.S. Pyndick, and D. L., Rubinfeld, Econometric Models and Economic Forcasts. Mc Graw-Hill Inc: Singapore, 1991.

[23] I. Haryono, Road Map 2007-2020, Industri Hasil Tembakau dan Kebijakan Cukai, Balittas, 2015.

[24] K. E. Warner, "The Role of Research in International Tobacco Control." American Journal of Public Health Vol 95, pp. 976-984, 2005.

[25] A A Patunru, A Rahardja. Trade Protectionism in Indonesia: Bad Times and Bad Policy. Analysis. Lowy Institute: Sydney

[26] Australia, 2015. Market Insider, Government initiatives raise Zanzibar clove output, 2014. http://www.intracen.org/itc/ blogs/ market-insider/Government-initiatives-raise-Zanzibar-cloveoutput/ 